\title{
Pyrenylamino Acids: Synthesis, Photophysical and Electrochemical Studies
}

\author{
Ana S. Abreu, ${ }^{[a, b]}$ Elisabete M. S. Castanheira, ${ }^{[b]}$ Paula M. T. Ferreira, ${ }^{*[a]}$ \\ Luís S. Monteiro, ${ }^{\text {[a] }}$ Goreti Pereira, ${ }^{\text {[a] }}$ and Maria-João R. P. Queiroz ${ }^{\text {a] }}$
}

Keywords: Dehydroamino acids / Pyrene / Cross-coupling / Cyclic voltammetry / Fluorescence

Several $\beta$-pyrenyldehydroamino acids and a pyrenylalanine derivative have been synthesized in good-to-high yields from dehydroamino acids by several types of reactions. A $\beta$ [(pyren-1-yl)methylamino]alanine was prepared by treating the methyl ester of $N, N$-(di-tert-butoxycarbonyl)dehydroalanine with (pyren-1-yl)methylamine hydrochloride in the presence of an excess of potassium carbonate. The $E$ isomer of the methyl esters of $N$-(tert-butoxycarbonyl)- $\beta$-(1,2,4triazol-1-yl)dehydroalanine and dehydroaminobutyric acid were treated with (pyren-1-yl)methylamine hydrochloride in the presence of triethylamine to give the $E$ isomers of the $\beta$ aminomethylpyrene dehydroalanine and dehydroaminobutyric acid derivatives. $\beta$-(Pyren-1-yl)dehydrophenylalanine and dehydroaminobutyric acid derivatives were obtained from the pure stereoisomer of the corresponding $\beta$-bromodehydroamino acids and (pyren-1-yl)boronic acid by Suzuki cross-coupling. This reaction was also applied successfully to $\beta$-bromodehydrodipeptides. The electrochemical behaviour of some of the compounds prepared was studied by cyclic voltammetry. The peak potentials for the oxidation and reduction of pyrenylalanines were similar to those reported for pyrene. However, it was found that when the pyrene ring was conjugated with the dehydroamino acid moiety, the compounds had higher oxidation and reduction peak potentials than pyrene. The fluorescence properties of four of the pyrenylamino acids synthesized were evaluated in cyclohexane and alcohols. The methyl ester of $N, N$-bis(tert-butoxycarbonyl)- $\beta$-[(pyren-1-yl)methylamino]alanine presented high fluorescence quantum yields in cyclohexane and ethanol $\left(\Phi_{\mathrm{F}}\right.$ $=0.45$ and 0.35 , respectively).

() Wiley-VCH Verlag GmbH \& Co. KGaA, 69451 Weinheim, Germany, 2008)

\section{Introduction}

In our group we have been interested in the synthesis of non-proteinogenic amino acids such as $\beta$-substituted alanines, ${ }^{[1]} \alpha$-aminoglycines, ${ }^{[2]}$ furanic amino acids, ${ }^{[3]} 4$-imidazolidinones $^{[4]}$ and $\beta, \beta$-diaryl- or heteroaryldehydroamino acids. ${ }^{[5]}$ The latter were synthesized by Suzuki cross-coupling reactions of a $\beta, \beta$-dibromodehydroalanine ${ }^{[5 a]}$ or of $\beta$ bromodehydrophenylalanine derivatives ${ }^{[5 b-5 \mathrm{~d}]}$ with several aryl- or heteroarylboronic acids. The study of the photophysical properties of some of the new amino acid derivatives indicated their possible use as fluorescent probes.

Pyrene possesses unique spectroscopic properties such as a high fluorescence quantum yield, a long excited-state lifetime and the ability to form excimers when two pyrene moieties (one excited and the other in the ground state) are in close proximity. Pyrenylalanine has been used as a fluorescent probe in peptides and proteins and there are several reports describing the synthesis and applications of this

[a] Department of Chemistry, University of Minho, Gualtar, 4710-057 Braga, Portugal Fax: +351-253604382

E-mail: pmf@quimica.uminho.pt

[b] Department of Physics, University of Minho, Gualtar, 4710-057 Braga, Portugal amino acid. ${ }^{[6]}$ With this in mind we decided to synthesize pyrenylamino acids by using several types of reactions developed by our group.

Previously, we found that $N, N$-diprotected dehydroalanine derivatives are excellent substrates in Michael addition reactions, allowing the preparation of a wide variety of new $\beta$-substituted alanines in high yields. ${ }^{[1,3 b]}$ Thus, a similar strategy was proposed for the synthesis of a pyrenylalanine derivative using the methyl ester of $N, N$-(di-tert-butoxycarbonyl)dehydroalanine as the Michael acceptor and (pyren1-yl)methylamine hydrochloride as the nucleophile.

In the course of our work concerning the reactivity of dehydroamino acids towards nucleophiles, it was found that it is possible to synthesize $\beta$-aminodehydroalanine and $\beta$ aminodehydroaminobutyric acid derivatives ${ }^{[3 b, 7]}$ by treating the $E$ isomer of $\beta$-(1,2,4-triazol-1-yl)dehydroamino acids with amines. This reaction proceeds by the replacement of the triazole group by the amine, giving the $E$ isomer of the corresponding $\beta$-aminodehydroamino acids. By using the same strategy we were able to synthesize $\beta$-[(pyren-1-yl)methylamino]dehydroamino acids in good-to-high yields.

We have also been interested in the synthesis of $\beta$-arylor -heteroaryldehydroamino acids. These compounds were prepared by Suzuki cross-coupling of $\beta$-bromodehydroamino acids with several aryl- or heteroarylboronic acids. ${ }^{[5]}$ Several $\beta$-pyrenyldehydroamino acid derivatives have been 
obtained by the Suzuki cross-coupling of $\beta$-bromodehydrophenylalanines and $\beta$-bromodehydroaminobutyric acids with (pyren-1-yl)boronic acid. The electrochemical and photophysical properties of some of the $\beta$-pyrenylamino acid derivatives synthesised were evaluated.

\section{Results and Discussion}

The methyl ester of $N, N$-bis(tert-butoxycarbonyl)- $\beta$ [(pyren-1-yl)methylamino]alanine (2) was obtained in $94 \%$ yield as a racemic mixture by Michael addition reaction between $N, N$-diprotected dehydroalanine derivative $\mathbf{1}$ and (pyren-1-yl)methylamine hydrochloride (Scheme 1).

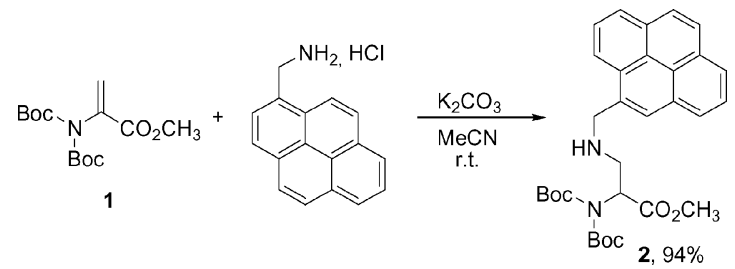

Scheme 1. Synthesis of the methyl ester of $N, N$-bis(tert-butoxycarbonyl)- $\beta-[($ pyren-1-yl)methylamino]alanine.

$\beta-[($ Pyren-1-yl)methylamino]dehydroamino acid derivatives were synthesized by using a strategy previously developed by us. The $E$ isomer of the $\beta$-(1,2,4-triazol-1-yl)dehydroamino acids $(E)-\mathbf{3} \mathbf{a}^{[7]}$ and $(E)-\mathbf{3} \mathbf{b}^{[7]}$ were treated with (pyren-1-yl)methylamine hydrochloride in methanol to give compounds $(E)-\mathbf{4}$ and $(E)-5$ in 84 and $45 \%$ yields, respectively (Scheme 2). The stereochemistries of compounds $(E)$ 4 and $(E)-5$ were determined by NOE difference experiments by irradiating the $\alpha-\mathrm{NH}$ proton and observing $\mathrm{NOE}$ enhancements of the signals of the $\beta-\mathrm{CH}$ or $\gamma-\mathrm{CH}_{3}$ protons.

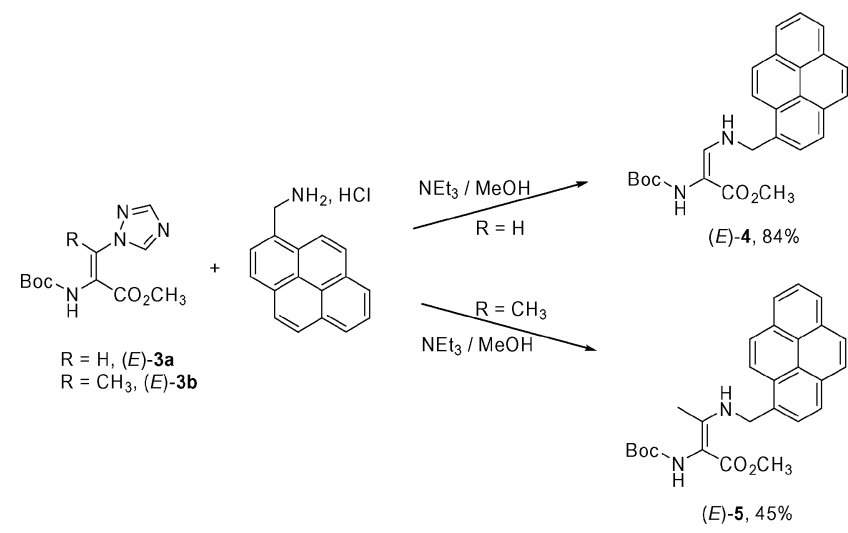

Scheme 2. Synthesis of the $E$ isomer of the methyl esters of $N$-(tertbutoxycarbonyl)- $\beta-[($ pyren-1-yl)methylamino]dehydroamino acids.

By using our Suzuki cross-coupling conditions ${ }^{[5]}$ we were able to prepare several $\beta$-(pyren-1-yl)dehydroaminobutyric acid and -dehydrophenylalanine derivatives. Thus, the pure stereoisomers of the methyl esters of $N$-(tert-butoxycarbonyl)- $\beta$-bromodehydroamino acids [compounds $(Z)-6,(E)$ -
6, $(Z)-7$ and $(E)-7]$ were treated with (pyren-1-yl)boronic acid to give, with retention of configuration, the corresponding $\beta$-(pyren-1-yl)dehydroamino acid in yields ranging from 72 to $96 \%$ [compounds $(Z)-8,(E)-\mathbf{8},(Z)-\mathbf{9}$ and (E)-9, Scheme 3, Table 1].

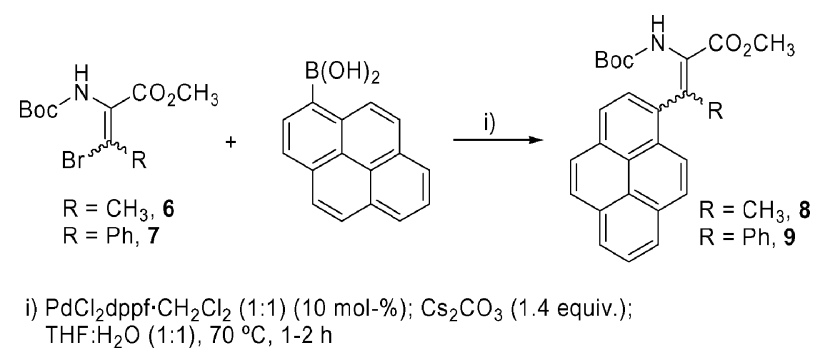

Scheme 3. Synthesis of the methyl esters of $N$-(tert-butoxycarbonyl)- $\beta$-(pyren-1-yl)dehydroamino acids.

Table 1. Results obtained in the synthesis of $\beta$-(pyren-1-yl)dehydroamino acids.

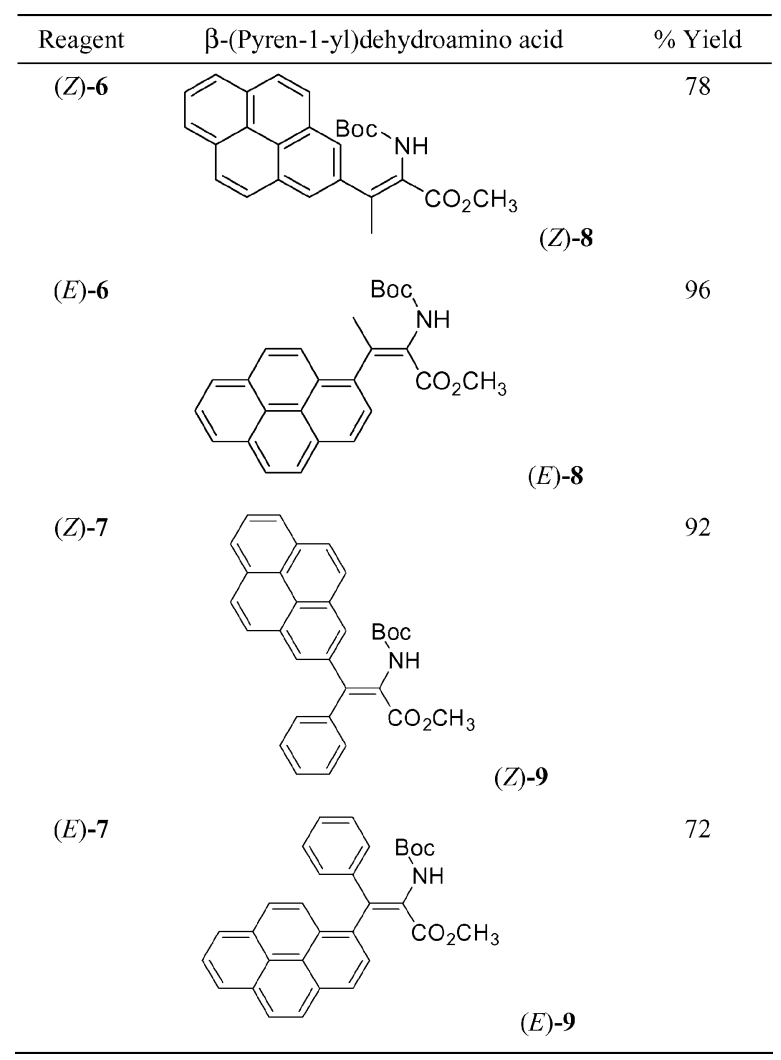

The same type of reaction was applied to the synthesis of $\beta$-(pyren-1-yl)dehydrodipeptides [compounds $(E)-\mathbf{1 2}$ and (Z)-13, Scheme 4]. Compound (E)-10 was prepared by dehydration followed by bromination with $\mathrm{N}$-bromosuccinimide (NBS) of the corresponding threonine dipeptide and isolation of the isomers by column chromatography.

The electrochemical behaviour and photophysical properties of compounds $\mathbf{2},(E)-\mathbf{4},(Z)-\mathbf{8},(E)-\mathbf{8},(Z)-\mathbf{9}$ and $(E)-\mathbf{1 2}$ (Scheme 5) were studied by cyclic voltammetry and absorption and emission spectroscopy. 

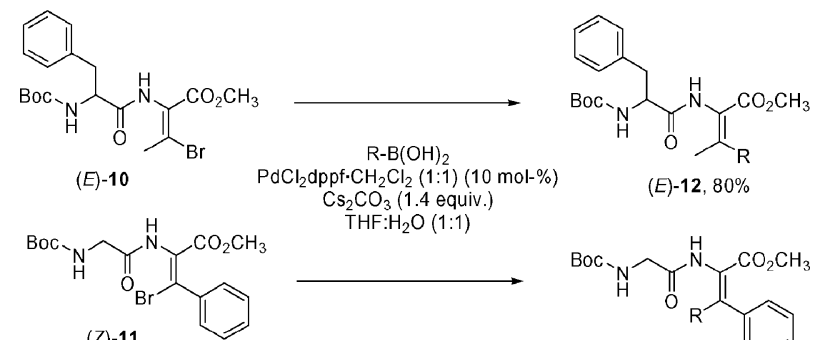

$(E)-12,80 \%$

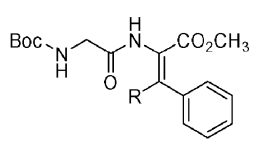

(Z)-13, $81 \%$

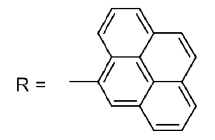

Scheme 4. Synthesis of the methyl esters of $N$-(tert-butoxycarbonyl)- $\beta$-(pyren-1-yl)dehydrodipeptides.
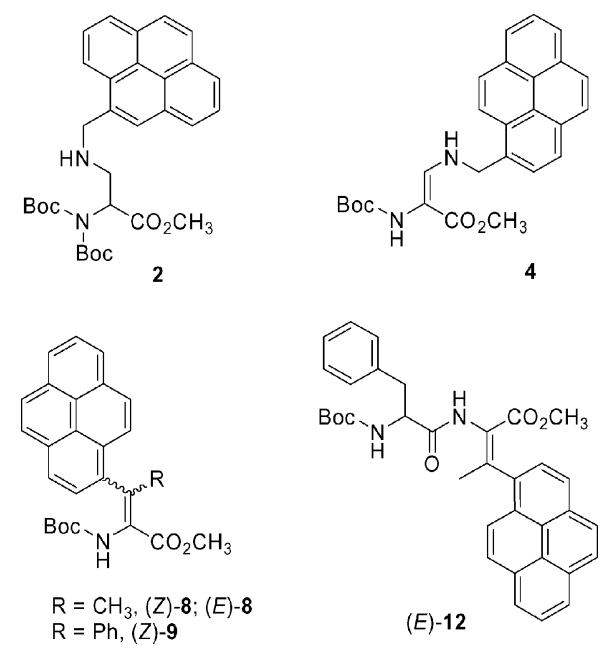

Scheme 5. $\beta$-(Pyrenyl)amino acid derivatives submitted to cyclic voltammetry and photophysical studies.

The peak potentials obtained by cyclic voltammetry of compounds 2, $(E)-\mathbf{4},(Z)-\mathbf{8}$ and $(Z)-\mathbf{9}$ are presented in Table 2. The peak potentials obtained for the oxidation and reduction of compounds $\mathbf{2}$ and $(E)-\mathbf{4}$ are similar to those reported in the literature for pyrene $\left(E_{\mathrm{p}}=-2.07 \mathrm{~V}\right.$ and $E_{\mathrm{p}}=$ $+1.10 \mathrm{~V}$ vs. $\mathrm{Ag} / \mathrm{AgCl}$, respectively) ${ }^{[8]}$ For compounds $(Z)-8$ and $(Z)-9$, both the reduction and oxidation potentials were higher than those reported for pyrene. The results obtained for compounds 2 and $(E)-4$ were expected because compound $\mathbf{2}$ is a pyrenylalanine derivative and in compound (E)-4 there is no conjugation between the pyrene moiety and the dehydroalanine. By comparing the results obtained for compound $(E)-\mathbf{4}$ with those for compounds $(Z)-\mathbf{8}$ and $(Z)-9$ in which the pyrene ring is conjugated with the $\alpha, \beta-$ double bond of the dehydroamino acid, we can conclude that this conjugation makes the pyrene nucleus easier to reduce and more difficult to oxidize. Also, compound $(Z)$ 9, due to the further conjugation with the phenyl group, shows higher reduction and oxidation peak potentials than compound $(Z)-8$.
Table 2. Peak potentials obtained by cyclic voltammetry of compounds $\mathbf{2},(E)-\mathbf{4},(Z)-\mathbf{8}$ and $(Z)-\mathbf{9}$. ${ }^{[a]}$

\begin{tabular}{lcc}
\hline Compound & $-E_{\mathrm{p}}[\mathrm{V}]$ vs. SCE & \\
\hline $\mathbf{2}$ & 1.96 & $E_{\mathrm{p}}[\mathrm{V}]$ vs. SCE \\
$(E)-\mathbf{4}$ & 2.06 & 1.05 \\
$(Z)-\mathbf{8}$ & 1.82 & 1.12 \\
$(Z)-\mathbf{9}$ & 1.70 & 1.58 \\
\end{tabular}

[a] Cathode: vitreous carbon; solvent: DMF; supporting electrolyte: $0.1 \mathrm{moldm}^{-3} \quad \mathrm{Bu}_{4} \mathrm{NBF}_{4}$; substrate concentration: $0.005 \mathrm{moldm}^{-3}$. [b] SCE: standard calomel electrode.

The absorption and fluorescence properties of compounds $\mathbf{2},(E)-\mathbf{8},(Z)-\mathbf{9}$ and $(E)$-12 were studied in cyclohexane and methanol (and also in ethanol for compound 2). The absorption $\left(\lambda_{\text {abs }}\right)$ and emission maxima $\left(\lambda_{\mathrm{em}}\right)$, molar extinction coefficients $(\varepsilon)$ and fluorescence quantum yields $\left(\Phi_{\mathrm{F}}\right)$ are presented in Table 3. The normalized absorption and fluorescence spectra of compounds $2,(E)-\mathbf{8},(Z)-\mathbf{9}$ and (E)-12 are shown in Figure 1.

The absorption spectra of all the compounds (Figure 1) show intense bands with high molar extinction coefficients at the lowest energy peak $(\log \varepsilon \geq 4.5$, Table 3$)$ typical of a $\pi-\pi^{*}$ transition. ${ }^{[9]}$ Compound 2 exhibits absorption and emission spectra that resemble those of pyrene, ${ }^{[10]}$ with high fluorescence quantum yields in cyclohexane and ethanol $\left(\Phi_{\mathrm{F}}=0.58\right.$ for pyrene in cyclohexane $\left.{ }^{[11]}\right)$.

The pyrenylamino acids $(E)-\mathbf{8}$ and $(E)$-12 show very similar absorption and fluorescence spectra (Figure 1). In the emission spectra, a redshift, loss of vibrational structure, and stronger tailing above $500 \mathrm{~nm}$ are observed relative to compound $\mathbf{2}$. The fluorescence quantum yields are markedly lower (Table 3 ). The conjugation of the dehydroamino acid double bond with the pyrene $\pi$ electrons leads to an increase in the non-radiative deactivation pathways. Some charge transfer (CT) character of the excited state may also be present, the conjugated $\mathrm{NH}$ group acting as the electron donor and the pyrenyl moiety as the acceptor. A strong excited-state CT has been observed in pyrene-dimethylaniline derivatives. ${ }^{[12,13]}$ In compounds $(E)-\mathbf{8}$ and $(E)-\mathbf{1 2}$, the electron-withdrawing properties of the tert-butoxycarbonyl group and of the methyl ester may contribute to a decrease in the CT character. The similarity of the spectral properties of the two pyrenylamino acids $(E)-\mathbf{8}$ and $(E)-\mathbf{1 2}$ indicates a negligible influence of the phenyl ring in compound $(E)-\mathbf{1 2}$.

Compound ( $Z$ )-9 exhibits the highest loss of vibrational structure in both absorption and fluorescence spectra (Figure 1). This behaviour can be attributed to the interaction between the $\pi$ systems of pyrene and the phenyl ring, which are close together in this compound, as previously detected for 1-phenylpyrene. ${ }^{[12,14]}$

The $\Phi_{\mathrm{F}}$ values are lower in alcohols for all compounds (Table 3). Besides the greater excited-state CT character expected in polar solvents, solute-solvent hydrogen-bonding interactions may play an important role, leading to enhanced singlet $\rightarrow$ triplet intersystem crossing efficiency. ${ }^{[9]}$ All four pyrenylamino acids have the possibility of establishing hydrogen bonds with protic solvents. Nevertheless, compound $\mathbf{2}$ has a very reasonable $\Phi_{\mathrm{F}}$ value in ethanol. 
Table 3. Absorption and emission maxima $\left(\lambda_{\mathrm{abs}}\right.$ and $\left.\lambda_{\mathrm{em}}\right)$, molar extinction coefficients $(\varepsilon)$ at absorption maxima and fluorescence quantum yields $\left(\Phi_{\mathrm{F}}\right)$ relative to anthracene in ethanol for compounds $\mathbf{2},(E)-\mathbf{8},(Z)-\mathbf{9}$ and $(E)-\mathbf{1 2}$ in cyclohexane $(\mathrm{CyHx})$, ethanol $(\mathrm{EtOH})$ and methanol $(\mathrm{MeOH})$.

\begin{tabular}{lllll}
\hline Compound & Solvent & $\lambda_{\text {abs }}[\mathrm{nm}](\varepsilon)\left[10^{4} \mathrm{M}^{-1} \mathrm{~cm}^{-1}\right]$ & $\lambda_{\mathrm{em}}[\mathrm{nm}]$ & $\Phi_{\mathrm{F}}$ \\
\hline $\mathbf{2}$ & $\mathrm{CyHx}$ & $343(5.23), 327(3.59), 276(4.78), 243(7.46)$ & $418,396,387,381,375$ & 0.45 \\
& $\mathrm{EtOH}$ & $342(6.08), 326(4.21), 276(5.53), 242(9.10)$ & $418,396,387,382,376$ & 0.35 \\
& $\mathrm{MeOH}$ & $341(5.04), 325(3.46), 275(4.01), 242(7.71)$ & $416,396,387,381,375$ & 0.07 \\
$(E)-\mathbf{8}$ & $\mathrm{CyHx}$ & $343(3.62), 328(2.55), 277(4.01), 243(6.01)$ & $444,419,395$ & 0.04 \\
& $\mathrm{MeOH}$ & $342(3.14), 327(2.21), 276(3.45), 241(5.53)$ & $420,398,388$ & 0.02 \\
$(Z)-\mathbf{9}$ & $\mathrm{CyHx}$ & $346(3.08), 278(4.14), 243(6.97)$ & $414,401,392$ & 0.09 \\
& $\mathrm{MeOH}$ & $348(3.40), 278(4.29), 241(7.90)$ & 421,397 & 0.01 \\
$(E)-\mathbf{1 2}$ & $\mathrm{CyHx}$ & $343(3.82), 328(2.67), 277(4.28), 243(6.38)$ & $445,420,396$ & 0.01 \\
& $\mathrm{MeOH}$ & $342(4.20), 327(2.96), 276(4.68), 241(7.60)$ & $419,398,389$ & \\
& &
\end{tabular}

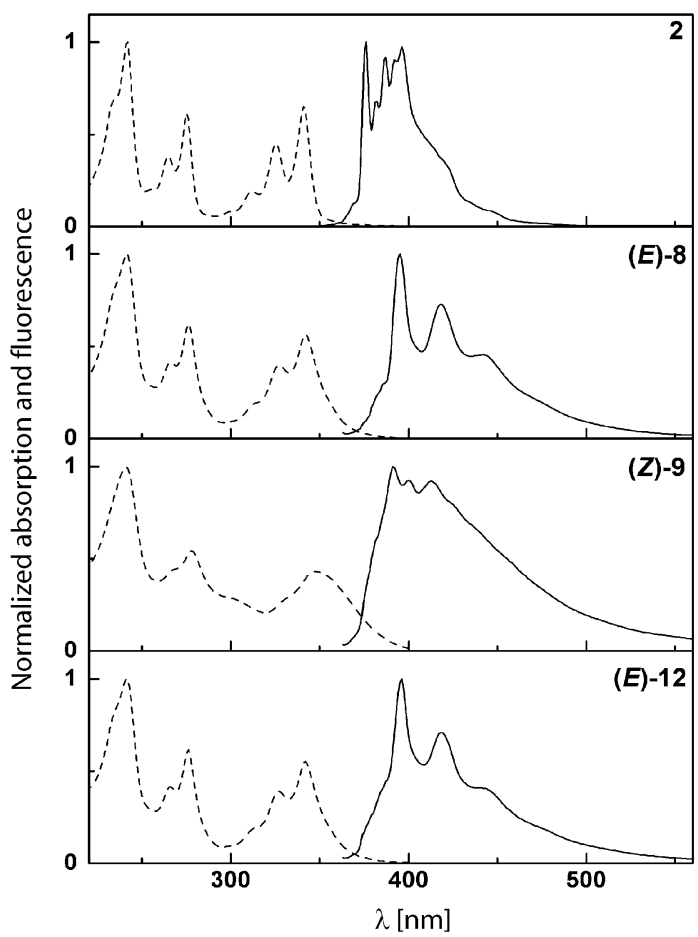

Figure 1. Normalized absorption (dashed lines) and fluorescence (solid lines) $\left(\lambda_{\mathrm{exc}}=342 \mathrm{~nm}\right)$ spectra of compounds 2, $(E)-\mathbf{8},(Z)-\mathbf{9}$ and $(E)-12$ in cyclohexane (concentrations are $2 \times 10^{-5} \mathrm{M}$ for absorption and $3 \times 10^{-6} \mathrm{M}$ for emission).

These results show that the compounds studied, after deprotection, can be inserted into peptides and proteins and be excited without simultaneous excitation of tryptophan or other aromatic amino acids (tyrosine and phenylalanine) that absorb light at $\lambda<300 \mathrm{~nm} .{ }^{[9,15]}$ Therefore, when deprotected, these compounds may be useful for conformational studies, especially the highly fluorescent $\beta-[($ pyren-1-yl)methylamino]alanine.

\section{Conclusions}

Several types of reactions, namely, Michael addition, substitution and Suzuki cross-coupling reactions, have been used to prepare pyrenylamino acid derivatives from $\alpha, \beta$-dehydroamino acids. Thus, a variety of pyrenyl amino and dehydroamino acids have been obtained in good-to-high yields. Cyclic voltammetry studies showed that pyrenylamino acids exhibit oxidation and reduction potentials similar to those of pyrene. However, when the pyrene moiety is conjugated with the $\alpha, \beta$-double bond of the dehydroamino acid derivative, the compounds are easier to reduce and more difficult to oxidize than pyrene. Fluorescence studies showed that when deprotected these pyrenylamino acids can be useful for conformational studies in peptides and proteins, especially the highly fluorescent $\beta-[($ pyren-1-yl)methylamino]alanine.

\section{Experimental Section}

General Methods: Melting points $\left[{ }^{\circ} \mathrm{C}\right]$ were determined with a Gallenkamp apparatus and are uncorrected. ${ }^{1} \mathrm{H}$ and ${ }^{13} \mathrm{C}$ NMR spectra were recorded with a Varian Unity Plus spectrometer at 300 and 75.4 MHz, respectively, and on a Bruker Avance $\mathrm{II}^{+}$spectrometer at 400 and $100.6 \mathrm{MHz}$, respectively. ${ }^{1} \mathrm{H}-{ }^{1} \mathrm{H}$ spin-spin decoupling and DEPT $\theta 45^{\circ}$ methods were used. Chemical shifts are given in ppm and coupling constants in Hz. HRMS (EI or ESI) spectra were recorded at the Mass Spectrometry Service of the University of Vigo, Spain. Elemental analysis was performed on a LECO CHNS 932 elemental analyser.

The reactions were monitored by thin-layer chromatography (TLC). Column chromatography was performed on Macherey-Nagel silica gel (230-400 mesh). Petroleum ether refers to the boiling range $40-60{ }^{\circ} \mathrm{C}$. When a solvent gradient was used, the polarity was increased from neat petroleum ether to mixtures of diethyl ether/ petroleum ether, with an increase of $10 \%$ diethyl ether in each step, until isolation of the product. $\left[\mathrm{PdCl}_{2} \mathrm{dppf} \cdot \mathrm{CH}_{2} \mathrm{Cl}_{2}\right](1: 1)$ refers to [1,1'-bis(diphenylphosphanyl)ferrocene]dichloropalladium(II) complexed to dichloromethane.

Cyclic voltammetry experiments were carried out by using a Hi-Tek DT 2101potentiostat and a Hi-Tek PPRl wave generator connected to a Philips PM 8043 recorder and a three-electrode, home-built glass cell.

Absorption spectra were recorded with a Shimadzu UV-3101PC UV/Vis/NIR spectrophotometer. Fluorescence measurements were performed by using a Fluorolog 3 spectrofluorimeter equipped with double monochromators for both excitation and emission. Fluorescence spectra were corrected for the instrumental response of the system. All spectroscopic measurements were performed at $25^{\circ} \mathrm{C}$.

To determine the fluorescence quantum yields, the solutions were previously bubbled for $1 \mathrm{~h}$ with ultrapure nitrogen. The fluorescence quantum yields $\left(\Phi_{\mathrm{s}}\right)$ were determined by using the standard 
method [Equation (1), where $A$ is the absorbance at the excitation wavelength, $F$ is the integrated emission area and $n$ is the refraction index of the solvents used; subscripts $r$ and $s$ refer to the reference and sample compounds]. ${ }^{[16,17]}$ Anthracene in ethanol was used as the reference $\left(\Phi_{\mathrm{r}}=0.27^{[18]}\right.$ at $\left.25^{\circ} \mathrm{C}\right)$.

$\Phi_{\mathrm{s}}=\left|\left(A_{\mathrm{r}} F_{\mathrm{S}} n_{\mathrm{s}}^{2}\right) /\left(A_{\mathrm{s}} F_{\mathrm{r}} n_{\mathrm{r}}^{2}\right)\right| \Phi_{\mathrm{r}}$

Synthesis of Compounds 1, (E)-3a, $(E)-3 \mathrm{~b},(Z)-6,(E)-6,(Z)-7,(E)-$ 7 and $(Z)-11$ : The synthesis of these compounds has been described elsewhere. ${ }^{[4,5,7,19]}$

Synthesis of Methyl 2-[Bis(tert-butoxycarbonyl)amino]-3-I(pyren-1yl)methylaminolpropanoate (2): (Pyren-1-yl)methylamine hydrochloride $(0.500 \mathrm{mmol})$, triethylamine $(1 \mathrm{mmol})$ and $\mathrm{K}_{2} \mathrm{CO}_{3}$ (6 equiv.) were added to a solution of $\mathbf{1}(0.500 \mathrm{mmol}, 151 \mathrm{mg})$ in acetonitrile $(5 \mathrm{~mL})$. The reaction mixture was stirred at room temperature for $48 \mathrm{~h}$ (the reaction was followed by ${ }^{1} \mathrm{H}$ NMR). The reaction mixture was filtered and the solvent removed under reduced pressure to give $2(249 \mathrm{mg}, 94 \%)$ as a white solid; m.p. $114.5-116.0{ }^{\circ} \mathrm{C}$ (from diethyl ether $/ n$-hexane). ${ }^{1} \mathrm{H}$ NMR $(400 \mathrm{MHz}$, DMSO): $\delta=1.34$ (s, $18 \mathrm{H}, \mathrm{CH}_{3}$ Boc), 3.05 (dd, $J=12.8, J=$ $\left.9.2 \mathrm{~Hz}, 1 \mathrm{H}, \beta \mathrm{CH}_{2}\right), 3.33\left(\mathrm{dd}, J=12.8, J=5.2 \mathrm{~Hz}, \beta \mathrm{CH}_{2}\right) 3.62(\mathrm{~s}$, $\left.3 \mathrm{H}, \mathrm{OCH}_{3}\right), 4.37\left(\mathrm{~d}, J=13.6 \mathrm{~Hz}, 1 \mathrm{H}, \mathrm{CH}_{2}\right), 4.46(\mathrm{~d}, J=13.6 \mathrm{~Hz}$, $\left.1 \mathrm{H}, \mathrm{CH}_{2}\right), 5.11(\mathrm{dd}, J=9.2, J=5.2 \mathrm{~Hz}, 1 \mathrm{H}, \alpha \mathrm{CH}), 8.05-8.28(\mathrm{~m}$, $8 \mathrm{H} \mathrm{ArH}), 8.43(\mathrm{~d}, J=9.2 \mathrm{~Hz}, 1 \mathrm{H}, \mathrm{ArH}) \mathrm{ppm} .{ }^{13} \mathrm{C} \mathrm{NMR}$ (100.6 MHz, DMSO): $\delta=27.43\left[\mathrm{C}\left(\mathrm{CH}_{3}\right)_{3}\right], 48.24\left(3-\mathrm{CH}_{2}\right), 50.23$ $\left(\mathrm{NHCH}_{2}\right), 51.93\left(\mathrm{OCH}_{3}\right), 57.54(2-\mathrm{CH}), 82.27\left[\mathrm{OC}\left(\mathrm{CH}_{3}\right)_{3}\right], 123.63$ $(\mathrm{CH}), 123.98(\mathrm{C}), 124.07(\mathrm{C}), 124.51(\mathrm{CH}), 124.92(\mathrm{CH}), 124.98$ $(\mathrm{CH}), 126.09(\mathrm{CH}), 126.75(\mathrm{CH}), 126.86(\mathrm{CH}), 127.06(\mathrm{CH}), 127.39$ $(\mathrm{CH}), 128.50$ (C), 129.85 (C), 130.34 (C), 130.77 (C), 134.45 (C), $151.70(\mathrm{C}=\mathrm{O}), 170.05(\mathrm{C}=\mathrm{O})$ ppm. $\mathrm{C}_{31} \mathrm{H}_{36} \mathrm{~N}_{2} \mathrm{O}_{6}$ (532.63): calcd. $\mathrm{C}$ 69.90, H 6.81, N 5.26; found C 69.86, H 6.76, N 5.21.

Synthesis of Methyl (E)-2-(tert-Butoxycarbonylamino)-3-[(pyren-1yl)methylamino|acrylate [(E)-4]: (Pyren-1-yl)methylamine hydrochloride $(0.550 \mathrm{mmol}, 147 \mathrm{mg})$ and triethylamine $(1 \mathrm{mmol})$ were added to a solution of (E)-3a $(0.500 \mathrm{mmol}, 134 \mathrm{mg})$ in methanol $(5 \mathrm{~mL})$. The reaction mixture was stirred at room temperature for $48 \mathrm{~h}$ (the reaction was followed by ${ }^{1} \mathrm{H}$ NMR). Ethyl acetate $(50 \mathrm{~mL})$ was added to the reaction mixture and the organic phase washed with water and brine $(2 \times 20 \mathrm{~mL})$. The organic layer was dried with $\mathrm{MgSO}_{4}$ and the solvent removed under reduced pressure to give (E)-4 (181 mg, 84\%) as a white solid; m.p. $151.0-152.0{ }^{\circ} \mathrm{C}$ (from diethyl ether $/ n$-hexane). ${ }^{1} \mathrm{H}$ NMR (400 MHz, DMSO): $\delta=$ 1.40 (s, $18 \mathrm{H}, \mathrm{CH}_{3} \mathrm{Boc}$ ), 3.49 (s, $3 \mathrm{H}, \mathrm{OCH}_{3}$ ), 5.08 (br. s, $2 \mathrm{H}, \mathrm{CH}_{2}$ ), 7.12-7.50 (m, $3 \mathrm{H}, \mathrm{ArH}+\mathrm{NH}), 8.06-8.29(\mathrm{~m}, 9 \mathrm{H}, \mathrm{ArH}) \mathrm{ppm} .{ }^{13} \mathrm{C}$ NMR (100.6 MHz, DMSO): $\delta=28.24\left[\mathrm{C}\left(\mathrm{CH}_{3}\right)_{3}\right], 47.91\left(\mathrm{CH}_{2}\right)$, $50.22\left(\mathrm{OCH}_{3}\right), 77.72\left[\mathrm{OC}\left(\mathrm{CH}_{3}\right)_{3}\right], 96.78(\mathrm{C}), 123.04(\mathrm{CH}), 123.88$ (C), $123.99(\mathrm{C}), 124.77(\mathrm{CH}), 125.15(\mathrm{CH}), 125.25(\mathrm{CH}), 126.08$ $(\mathrm{CH}), 126.24(\mathrm{CH}), 127.03(\mathrm{CH}), 127.38(\mathrm{CH}), 127.55(\mathrm{CH}), 127.71$ (C), 130.12 (C), 130.29 (C), 130.78 (C), 133.57 (C), $146.25(\mathrm{CH})$, $155.16(\mathrm{C}=\mathrm{O}), 166.41(\mathrm{C}=\mathrm{O})$ ppm. $\mathrm{C}_{26} \mathrm{H}_{26} \mathrm{~N}_{2} \mathrm{O}_{4}(430.50)$ : calcd. $\mathrm{C}$ 72.54, H 6.09, N 6.51; found C 71.92, H 5.64, N 6.69.

Synthesis of Methyl (E)-2-(tert-Butoxycarbonylamino)-3-I(pyren-1yl)methylamino]but-2-enoate [(E)-5]: (Pyren-1-yl)methylamine hydrochloride $(0.55 \mathrm{mmol}, 147 \mathrm{mg})$ and triethylamine $(1 \mathrm{mmol})$ were added to a solution of $(E)-3 \mathbf{b}(0.500 \mathrm{mmol}, 141 \mathrm{mg})$ in methanol $(5 \mathrm{~mL})$. The reaction mixture was stirred at room temperature for $48 \mathrm{~h}$ (the reaction was followed by ${ }^{1} \mathrm{H}$ NMR spectroscopy). Ethyl acetate $(50 \mathrm{~mL})$ was added to the reaction mixture and the organic phase washed with water and brine $(2 \times 20 \mathrm{~mL})$. The organic layer was dried with $\mathrm{MgSO}_{4}$ and the solvent removed under reduced pressure to give $(E)-5(100 \mathrm{mg}, 45 \%)$ as a white solid; m.p. 159.0 $160.0^{\circ} \mathrm{C}$ (from diethyl ether $/ n$-hexane). ${ }^{1} \mathrm{H}$ NMR $(400 \mathrm{MHz}$,
DMSO): $\delta=1.38$ (s, $\left.18 \mathrm{H}, \mathrm{CH}_{3} \mathrm{Boc}\right), 2.05\left(\mathrm{~s}, 3 \mathrm{H}, \gamma \mathrm{CH}_{3}\right), 3.51$ (s, $3 \mathrm{H}, \mathrm{OCH}_{3}$ ), 5.21 (br. s, $2 \mathrm{H}, \mathrm{CH}_{2}$ ), 7.34 (s, $\left.1 \mathrm{H}, \mathrm{NH}\right), 8.08-8.36$ (m, $9 \mathrm{H}, \mathrm{ArH}), 9.33-9.36(\mathrm{~m}, 1 \mathrm{H}, \mathrm{NH}) \mathrm{ppm} .{ }^{13} \mathrm{C} \mathrm{NMR}(100.6 \mathrm{MHz}$,

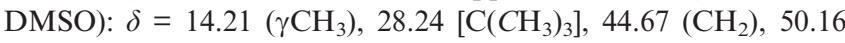
$\left(\mathrm{OCH}_{3}\right), 77.64\left[\mathrm{OC}\left(\mathrm{CH}_{3}\right)_{3}\right], 93.09(\mathrm{C}), 122.74(\mathrm{CH}), 122.87(\mathrm{CH})$, $123.87(\mathrm{C}), 124.14(\mathrm{C}), 124.94(\mathrm{CH}), 125.05(\mathrm{CH}), 125.33(\mathrm{CH})$, $125.46(\mathrm{CH}), 126.05(\mathrm{CH}), 126.41(\mathrm{CH}), 127.36(\mathrm{CH}), 127.75(\mathrm{C})$, $127.92(\mathrm{CH}), 130.29(\mathrm{C}), 130.38(\mathrm{C}), 130.80(\mathrm{C}), 132.24(\mathrm{C}), 132.66$ (C), $155.69(\mathrm{C}=\mathrm{O}), 168.62(\mathrm{C}=\mathrm{O}) \mathrm{ppm}$. HRMS (EI): calcd. for $\mathrm{C}_{27} \mathrm{H}_{28} \mathrm{~N}_{2} \mathrm{O}_{4}$ 444.2049; found 444.2039.

General Procedure for the Synthesis of $\boldsymbol{\beta}$-(Pyren-1-yl)dehydroamino Acid Derivatives: (Pyren-1-yl)boronic acid (1.5 equiv.), $\left[\mathrm{PdCl}_{2} \mathrm{dppf} \cdot \mathrm{CH}_{2} \mathrm{Cl}_{2}\right](1: 1)(10 \mathrm{~mol}-\%)$ and $\mathrm{Cs}_{2} \mathrm{CO}_{3}$ (1.4 equiv.) were added to a solution of the $\beta$-bromodehydroamino acid derivative in $\mathrm{THF} / \mathrm{H}_{2} \mathrm{O}(1: 1)$. The reaction mixture was heated at $70^{\circ} \mathrm{C}$ (the reaction was followed by TLC). The solvent was removed under reduced pressure and the residue dissolved in ethyl acetate $(100 \mathrm{~mL})$. The organic layer was washed with water and brine $\left(2 \times 30 \mathrm{~mL}\right.$ each), dried with $\mathrm{MgSO}_{4}$ and the solvent removed. The residue was submitted to column chromatography.

Synthesis of Methyl (Z)-2-(tert-Butoxycarbonylamino)-3-(pyren-1yl)but-2-enoate $[(Z)-8]$ : Compound $(Z)-8$ was prepared from compound $(Z)-6(0.500 \mathrm{mmol}, 147 \mathrm{mg})$ according to the general procedure described above, heating for $1 \mathrm{~h}$. Column chromatography using diethyl ether/petroleum ether (4:1) gave (Z)-8 (161 mg, 78\%) as a white solid; m.p. $183.0-184.0^{\circ} \mathrm{C}$ (from diethyl ether/petroleum ether). ${ }^{1} \mathrm{H}$ NMR (400 MHz, $\left.\mathrm{CDCl}_{3}\right): \delta=1.26$ (s, $9 \mathrm{H}, \mathrm{CH}_{3} \mathrm{Boc}$ ), $2.47\left(\mathrm{~s}, 3 \mathrm{H}, \gamma \mathrm{CH}_{3}\right), 3.98\left(\mathrm{~s}, 3 \mathrm{H}, \mathrm{OCH}_{3}\right), 5.51$ (br. s, $\left.1 \mathrm{H}, \mathrm{NH}\right)$, $7.82(\mathrm{~d}, J=6.8 \mathrm{~Hz}, 1 \mathrm{H}, \mathrm{ArH}), 8.03-8.23(\mathrm{~m}, 8 \mathrm{H}, \mathrm{ArH}) \mathrm{ppm} .{ }^{13} \mathrm{C}$ NMR (100.6 MHz, $\left.\mathrm{CDCl}_{3}\right): \delta=21.54\left(\gamma \mathrm{CH}_{3}\right), 27.97\left[\mathrm{C}\left(\mathrm{CH}_{3}\right)_{3}\right]$, $52.12\left(\mathrm{OCH}_{3}\right), 80.67\left[\mathrm{OC}\left(\mathrm{CH}_{3}\right)_{3}\right], 123.83(\mathrm{CH}), 124.76(\mathrm{C}), 124.96$ (C), $125.19(\mathrm{CH}), 125.35(\mathrm{CH}), 125.49(\mathrm{CH}), 126.08(\mathrm{C}), 126.21$ $(\mathrm{CH}), 127.10(\mathrm{C}), 127.17(\mathrm{CH}), 127.82(\mathrm{CH}), 128.50(\mathrm{CH}), 130.93$ (C), 131.95 (C), 131.21 (C), 132.14 (C), 134.53 (C), 153.00 (C=O), $165.68(\mathrm{C}=\mathrm{O})$ ppm. HRMS (EI): calcd. for $\mathrm{C}_{26} \mathrm{H}_{25} \mathrm{NO}_{4} 415.17836$; found 415.17843 .

Synthesis of Methyl (E)-2-(tert-Butoxycarbonylamino)-3-(pyren-1yl)but-2-enoate $[(\boldsymbol{E})-\mathbf{8}]$ : Compound $(E)-\mathbf{8}$ was prepared from compound $(E)-6(0.250 \mathrm{mmol}, 73.5 \mathrm{mg})$ according to the general procedure described above, heating for $1 \mathrm{~h}$. Column chromatography using diethyl ether/petroleum ether (1:4) gave $(E)-8(100 \mathrm{mg}, 96 \%)$ as a white solid; m.p. $205.0-206.0{ }^{\circ} \mathrm{C}$ (from diethyl ether/petroleum ether). ${ }^{1} \mathrm{H}$ NMR (400 MHz, $\mathrm{CDCl}_{3}$ ): $\delta=1.60$ (s, $9 \mathrm{H}, \mathrm{CH}_{3} \mathrm{Boc}$ ), 2.37 (s, $\left.3 \mathrm{H}, \gamma \mathrm{CH}_{3}\right), 3.18$ (s, $\left.3 \mathrm{H}, \mathrm{OCH}_{3}\right), 6.35$ (br. s, $1 \mathrm{H}, \mathrm{NH}$ ), $7.77(\mathrm{~d}, J=7.6 \mathrm{~Hz}, 1 \mathrm{H}, \operatorname{ArH}), 8.01(\mathrm{t}, J=7.6 \mathrm{~Hz}, 1 \mathrm{H}, \mathrm{ArH})$, 8.07-8.20 (m, $7 \mathrm{H}, \mathrm{ArH}) \mathrm{ppm} .{ }^{13} \mathrm{C} \mathrm{NMR}\left(100.6 \mathrm{MHz}, \mathrm{CDCl}_{3}\right): \delta$ $=23.34\left(\gamma \mathrm{CH}_{3}\right), 28.31\left[\mathrm{C}_{\left.\left(\mathrm{CH}_{3}\right)_{3}\right],} 51.61\left(\mathrm{OCH}_{3}\right), 80.76[\mathrm{OC}-\right.$ $\left.\left(\mathrm{CH}_{3}\right)_{3}\right], 124.50(\mathrm{CH}), 124.61(\mathrm{CH}), 124.66(\mathrm{CH}), 124.83(\mathrm{C})$, $124.95(\mathrm{CH}), 125.02(\mathrm{CH}), 125.26(\mathrm{C}), 125.90(\mathrm{CH}), 127.20(\mathrm{CH})$, $127.37(\mathrm{CH}), 127.58(\mathrm{C}), 127.66(\mathrm{CH}), 130.42(\mathrm{C}), 131.00(\mathrm{C})$, 131.31 (C), 136.93 (C), 141.81 (C), $153.46 \quad(\mathrm{C}=\mathrm{O}), 165.06$ $(\mathrm{C}=\mathrm{O})$ ppm. $\mathrm{C}_{26} \mathrm{H}_{25} \mathrm{NO}_{4}$ (415.48): calcd. C 75.16, H 6.06, N 3.37; found C 75.19, H 6.16, N 3.45 .

Synthesis of Methyl (Z)-2-(tert-Butoxycarbonylamino)-3-phenyl-3(pyren-1-yl)acrylate $[(Z)-9]$ : Compound $(Z)-9$ was prepared from compound (Z)-7 $(0.250 \mathrm{mmol}, 89.0 \mathrm{mg})$ according to the general procedure described above, heating for $1.5 \mathrm{~h}$. Column chromatography using diethyl ether/petroleum ether (1:1) gave $(Z)-9(110 \mathrm{mg}$, $92 \%$ ) as a white solid; m.p. $175.0-176.0^{\circ} \mathrm{C}$ (from diethyl ether/petroleum ether). ${ }^{1} \mathrm{H}$ NMR (400 MHz, $\left.\mathrm{CDCl}_{3}\right): \delta=1.24\left(\mathrm{~s}, 9 \mathrm{H}, \mathrm{CH}_{3}\right.$ Boc), 3.72 (s, $3 \mathrm{H}, \mathrm{OCH}_{3}$ ), 5.71 (br. s, $\left.1 \mathrm{H}, \mathrm{NH}\right), 7.24-7.28$ (m, 5 $\mathrm{H}, \mathrm{ArH}), 7.75(\mathrm{~d}, J=7.6 \mathrm{~Hz}, 1 \mathrm{H}, \mathrm{ArH}), 8.03-8.27(\mathrm{~m}, 8 \mathrm{H}$, 
ArH) ppm. ${ }^{13} \mathrm{C}$ NMR (100.6 MHz, $\left.\left.\mathrm{CDCl}_{3}\right): \delta=27.99\left[\mathrm{C} \mathrm{CH}_{3}\right)_{3}\right]$, $52.25\left(\mathrm{OCH}_{3}\right), 81.27\left[\mathrm{OC}\left(\mathrm{CH}_{3}\right)_{3}\right], 124.32(\mathrm{CH}), 124.68(\mathrm{C}), 125.05$ (C), $125.11(\mathrm{CH}), 125.48(\mathrm{CH}), 125.65(\mathrm{CH}), 126.26(\mathrm{CH}), 127.17$ $(\mathrm{CH}), 127.82(\mathrm{CH}), 128.04(\mathrm{CH}), 128.14(\mathrm{CH}), 128.19(2 \times \mathrm{CH})$, $128.45(\mathrm{C}), 128.67(2 \times \mathrm{CH}), 128.75(\mathrm{CH}), 130.90(\mathrm{C}), 131.20(\mathrm{C})$, 131.33 (C), 132.68 (C), 140.06 (C), $152.62 \quad(\mathrm{C}=\mathrm{O}), 166.41$ $(\mathrm{C}=\mathrm{O})$ ppm. $\mathrm{C}_{31} \mathrm{H}_{27} \mathrm{NO}_{4}$ (477.55): calcd. C 77.97, H 5.70, N 2.93; found $\mathrm{C} 77.60, \mathrm{H} 5.76, \mathrm{~N} 3.03$.

Synthesis of Methyl (E)-2-(tert-Butoxycarbonylamino)-3-phenyl-3(pyren-1-yl)acrylate $[(\boldsymbol{E})-9]$ : Compound $(E)-9$ was prepared from compound $(E)-7(0.400 \mathrm{mmol}, 145 \mathrm{mg})$ according to the general procedure described above, heating for $2 \mathrm{~h}$. Column chromatography using diethyl ether/petroleum ether (1:2) gave $(E)-\mathbf{9}(140 \mathrm{mg}$, $72 \%$ ) as a white solid; m.p. $200.0-201.0{ }^{\circ} \mathrm{C}$ (from diethyl ether/petroleum ether). ${ }^{1} \mathrm{H}$ NMR $\left(400 \mathrm{MHz}, \mathrm{CDCl}_{3}\right): \delta=1.50\left(\mathrm{~s}, 9 \mathrm{H}, \mathrm{CH}_{3}\right.$ Boc), 3.14 (s, $3 \mathrm{H}, \mathrm{OCH}_{3}$ ), 6.47 (br. s, $1 \mathrm{H}, \mathrm{NH}$ ), 7.27-7.37 (m, 5 $\mathrm{H}, \mathrm{ArH}), 7.85(\mathrm{~d}, J=8.0 \mathrm{~Hz}, 1 \mathrm{H}, \mathrm{ArH}), 7.98-8.19(\mathrm{~m}, 8 \mathrm{H}$, $\mathrm{ArH}) \mathrm{ppm} .{ }^{13} \mathrm{C} \mathrm{NMR}\left(100.6 \mathrm{MHz}, \mathrm{CDCl}_{3}\right): \delta=28.19\left[\mathrm{C}\left(\mathrm{CH}_{3}\right)_{3}\right]$, $51.81\left(\mathrm{OCH}_{3}\right), 81.40\left[\mathrm{OC}\left(\mathrm{CH}_{3}\right)_{3}\right], 124.43(\mathrm{CH}), 124.66(\mathrm{C}), 124.92$ (C), $125.05(\mathrm{CH}), 125.14(\mathrm{CH}), 125.21(\mathrm{CH}), 126.01(\mathrm{CH}), 127.35$ $(\mathrm{CH}), 127.61(\mathrm{CH}), 127.67(\mathrm{CH}), 127.73(\mathrm{CH}), 127.79(\mathrm{C}), 128.25$ $(2 \times \mathrm{CH}), 128.83(2 \times \mathrm{CH}), 129.26(\mathrm{CH}), 129.33(\mathrm{C}), 130.88(\mathrm{C})$, 131.01 (C), 131.26 (C), 132.98 (C), 134.65 (C), 138.93 (C), 152.96 $(\mathrm{C}=\mathrm{O}), 166.06(\mathrm{C}=\mathrm{O}) \mathrm{ppm}$. HRMS $(\mathrm{EI})$ : calcd. for $\mathrm{C}_{31} \mathrm{H}_{27} \mathrm{NO}_{4}$ 477.1940; found 477.1943.

Synthesis of Boc-L-Phe-Z- $\Delta$ Abu-OMe: DMAP (0.1 equiv.) was added followed by di-tert-butyl dicarbonate (1.0 equiv.) to a solution of Boc-L-Phe-L-Thr-OMe $(2.00 \mathrm{mmol}, 0.67 \mathrm{~g})$ in dry acetonitrile $\left(1 \mathrm{moldm}^{-3}\right)$ under rapid stirring at room temperature. The reaction was monitored by TLC (diethyl ether/n-hexane, $1: 1$ ) until all the reactant had been consumed. Then, $2 \%$ in volume of TMG was added and stirring was continued and the reaction followed by TLC. When all the reactant had been consumed, evaporation at reduced pressure gave a residue that was partitioned between diethyl ether $(100 \mathrm{~mL})$ and $\mathrm{KHSO}_{4}\left(1 \mathrm{~mol} \mathrm{dm}^{-3}, 30 \mathrm{~mL}\right)$. The organic phase was thoroughly washed with $\mathrm{KHSO}_{4}\left(1 \mathrm{moldm}{ }^{-3}\right), \mathrm{NaHCO}_{3}$ $\left(1 \mathrm{moldm}^{-3}\right)$ and saturated brine $(2 \times 30 \mathrm{~mL}$ each $)$, and dried with $\mathrm{MgSO}_{4}$. Removal of the solvent afforded Boc-L-Phe- $Z-\Delta$ Abu-OMe $(660 \mathrm{mg}, 91 \%)$ as a white solid; m.p. $93.0-94.0{ }^{\circ} \mathrm{C}$ (from diethyl ether $n$-hexane). ${ }^{1} \mathrm{H}$ NMR $\left(300 \mathrm{MHz}, \mathrm{CDCl}_{3}\right): \delta=1.40(\mathrm{~s}, 9 \mathrm{H}$, $\mathrm{CH}_{3}$ Boc), 1.68 (d, $\left.J=6.9 \mathrm{~Hz}, 3 \mathrm{H}, \gamma \mathrm{CH}_{3} \Delta \mathrm{Abu}\right), 3.03-3.22$ (m, 2 $\mathrm{H}, \mathrm{\beta CH}_{2} \mathrm{Phe}$ ), 3.73 (s, $3 \mathrm{H}, \mathrm{OCH}_{3}$ ), 4.49-5.13 (m, $1 \mathrm{H}, \alpha \mathrm{CH} \mathrm{Phe}$ ), $5.12(\mathrm{~d}, J=7.5 \mathrm{~Hz}, 1 \mathrm{H}, \mathrm{NH}), 6.79(\mathrm{q}, J=6.9 \mathrm{~Hz}, 1 \mathrm{H}, \beta \mathrm{CH}$ $\Delta \mathrm{Abu}), 7.21-7.33(\mathrm{~m}, 5 \mathrm{H}, \mathrm{ArH}), 7.50(\mathrm{~s}, 1 \mathrm{H}, \mathrm{NH}) \mathrm{ppm} .{ }^{13} \mathrm{C} \mathrm{NMR}$ $\left(75.4 \mathrm{MHz}, \mathrm{CDCl}_{3}\right): \delta=14.47\left(\gamma \mathrm{CH}_{3} \Delta \mathrm{Abu}\right), 28.18\left[\left(\mathrm{CH}_{3}\right)_{3} \mathrm{C}\right]$, $37.96\left(\beta_{2} \mathrm{CH}_{2} \mathrm{Phe}\right), 52.26\left(\mathrm{OCH}_{3}\right), 55.82(\alpha \mathrm{CH}$ Phe $), 80.35$ $\left[\left(\mathrm{CH}_{3}\right)_{3} \mathrm{C}\right], 125.70(\mathrm{C}), 126.92(\mathrm{CH}), 128.62(\mathrm{CH}), 129.34(\mathrm{CH})$, $134.54(\mathrm{CH}), 136.39(\mathrm{C}), 155.50(\mathrm{C}=\mathrm{O}), 164.60(\mathrm{C}=\mathrm{O}), 169.74$ $(\mathrm{C}=\mathrm{O})$ ppm. $\mathrm{C}_{19} \mathrm{H}_{26} \mathrm{~N}_{2} \mathrm{O}_{5}$ (362.42): calcd. C 62.97, H 7.23, N 7.73; found $\mathrm{C}$ 62.84, $\mathrm{H}$ 7.33, N 7.56.

Synthesis of Boc-L-Phe- $\Delta \mathrm{Abu}(\boldsymbol{\beta}-\mathrm{Br})-\mathrm{OMe}(\mathbf{1 0 )})$ Boc-L-Phe- $Z-\Delta \mathrm{Abu}-$ OMe $(1 \mathrm{mmol}, \quad 0.362 \mathrm{~g})$ was dissolved in dichloromethane $\left(0.1 \mathrm{moldm}^{-3}\right)$ and $N$-bromosuccinimide ( 2.5 equiv.) was added with vigorous stirring. After reacting for $16 \mathrm{~h}$, triethylamine (1.5 equiv.) was added and stirring was continued for $30 \mathrm{~min}$. The solvent was then evaporated at reduced pressure and the residue partitioned between dichloromethane $(100 \mathrm{~mL})$ and $\mathrm{KHSO}_{4}$ $\left(1 \mathrm{moldm}^{-3}, 50 \mathrm{~mL}\right)$. The organic phase was washed with $\mathrm{KHSO}_{4}$ $\left(1 \mathrm{moldm}^{-3}\right), \mathrm{NaHCO}_{3}\left(1 \mathrm{moldm}^{-3}\right)$ and brine $(3 \times 30 \mathrm{~mL}$ each $)$. After drying with $\mathrm{MgSO}_{4}$ the extract was taken to dryness at reduced pressure to give Boc-L-Phe- $\triangle \mathrm{Abu}(\beta-\mathrm{Br})-\mathrm{OMe}(397 \mathrm{mg}, 90 \%)$ as a 1:1 mixture of $E$ and $Z$ isomers. Column chromatography in diethyl ether/petroleum ether (1:4) afforded Boc-L-Phe- $E$ - $\Delta \mathrm{Abu}(\beta$ $\mathrm{Br}$ )-OMe $[(E)-10]$ as a white solid; m.p. $119.0-119.5^{\circ} \mathrm{C}$ (from diethyl ether/ $n$-hexane). ${ }^{1} \mathrm{H}$ NMR (300 $\left.\mathrm{MHz}, \mathrm{CDCl}_{3}\right): \delta=1.40$ (s, 9 $\mathrm{H}, \mathrm{CH}_{3} \mathrm{Boc}$ ), 2.21 (s, $\left.3 \mathrm{H}, \gamma \mathrm{CH}_{3} \Delta \mathrm{Abu}\right), 3.01-3.17\left(\mathrm{~m}, 2 \mathrm{H}, \beta \mathrm{CH}_{2}\right.$ Phe), 3.77 (s, $\left.3 \mathrm{H}, \mathrm{OCH}_{3}\right), 4.41-4.45(\mathrm{~m}, 1 \mathrm{H}, \alpha \mathrm{CH} \mathrm{Phe}), 5.12$ (s, $1 \mathrm{H}, \mathrm{NH}), 7.21-7.34$ (m, $5 \mathrm{H}, \mathrm{ArH}), 7.86$ (s, $1 \mathrm{H}, \mathrm{NH}) \mathrm{ppm} .{ }^{13} \mathrm{C}$ NMR $\left(75.4 \mathrm{MHz}, \mathrm{CDCl}_{3}\right): \delta=25.53\left(\gamma \mathrm{CH}_{3} \Delta \mathrm{Abu}\right), 28.18$ $\left[\left(\mathrm{CH}_{3}\right)_{3} \mathrm{C}\right], 37.36\left(\mathrm{BCH}_{2} \mathrm{Phe}\right), 52.36\left(\mathrm{OCH}_{3}\right), 55.47(\alpha \mathrm{CH} \mathrm{Phe})$, $80.78\left[\left(\mathrm{CH}_{3}\right)_{3} \mathrm{C}\right], 122.97(\mathrm{C}), 125.58(\mathrm{CH}), 127.05(\mathrm{CH}), 128.72$ $(\mathrm{CH}), 129.27(\mathrm{CH}), 136.20(\mathrm{C}), 155.82(\mathrm{C}=\mathrm{O}), 163.82(\mathrm{C}=\mathrm{O})$, $169.69(\mathrm{C}=\mathrm{O}) \mathrm{ppm} . \mathrm{C}_{19} \mathrm{H}_{25} \mathrm{BrN}_{2} \mathrm{O}_{5}$ (441.32): calcd. C 51.71, $\mathrm{H}$ 5.71, N 6.35; found C 51.34, H 5.65, N 6.69.

Boc-Phe- $Z-\triangle \mathrm{Abu}(\beta-\mathrm{Br})-\mathrm{OMe}[(Z)-10]$ was also isolated as white solid; m.p. $109.0-110.0{ }^{\circ} \mathrm{C} .{ }^{1} \mathrm{H}$ NMR $\left(300 \mathrm{MHz}, \mathrm{CDCl}_{3}\right): \delta=1.41$ (s, $9 \mathrm{H}, \mathrm{CH}_{3} \mathrm{Boc}$ ), 2.54 (s, $\left.3 \mathrm{H}, \gamma \mathrm{CH}_{3} \Delta \mathrm{Abu}\right), 3.05-3.19(\mathrm{~m}, 2 \mathrm{H}$, $\beta \mathrm{CH}_{2}$ Phe), 3.80 (s, $3 \mathrm{H}, \mathrm{OCH}_{3}$ ), 4.47-4.49 (m, $1 \mathrm{H}, \alpha \mathrm{CH}$ Phe), $4.98(\mathrm{~d}, J=6.6 \mathrm{~Hz}, 1 \mathrm{H}, \mathrm{NH}), 7.22-7.35(\mathrm{~m}, 5 \mathrm{H}, \mathrm{ArH}), 7.77$ (s, 1 $\mathrm{H}, \mathrm{NH}) \mathrm{ppm} .{ }^{13} \mathrm{C} \mathrm{NMR}\left(75.4 \mathrm{MHz}, \mathrm{CDCl}_{3}\right): \delta=24.61\left(\gamma \mathrm{CH}_{3}\right.$ $\Delta \mathrm{Abu}), 28.21\left[\left(\mathrm{CH}_{3}\right)_{3} \mathrm{C}\right], 37.35\left(\beta_{\mathrm{CH}} \mathrm{Phe}\right), 52.55\left(\mathrm{OCH}_{3}\right), 55.22$ $(\alpha \mathrm{CH}$ Phe $), 80.58\left[\left(\mathrm{CH}_{3}\right)_{3} \mathrm{C}\right], 124.41(\mathrm{C}), 126.57(\mathrm{C}), 127.03(\mathrm{CH})$, $128.71(\mathrm{CH}), 129.33(\mathrm{CH}), 136.12(\mathrm{C}), 155.47(\mathrm{C}=\mathrm{O}), 162.75$ $(\mathrm{C}=\mathrm{O}), 169.64(\mathrm{C}=\mathrm{O}) \mathrm{ppm} . \mathrm{C}_{19} \mathrm{H}_{25} \mathrm{BrN}_{2} \mathrm{O}_{5}$ (441.32): calcd. $\mathrm{C}$ 51.71, H 5.71, N 6.35; found C 51.73, H 5.60, N 6.64.

Synthesis of Compound $(\boldsymbol{E})-\mathbf{1 2}$ : Compound $(E)-\mathbf{1 2}$ was prepared from compound $(E)-\mathbf{1 0}(0.250 \mathrm{mmol}, 110 \mathrm{mg})$ according to the general procedure described above, heating for $1 \mathrm{~h}$. Column chromatography using diethyl ether/petroleum ether (1:1) gave $(E)$ $12(113 \mathrm{mg}, 80 \%)$ as a white solid; m.p. $129.5-130.5^{\circ} \mathrm{C}$ (from diethyl ether/petroleum ether). ${ }^{1} \mathrm{H}$ NMR $\left(400 \mathrm{MHz}, \mathrm{CDCl}_{3}\right): \delta=1.48$ (s, $9 \mathrm{H}, \mathrm{CH}_{3}$ Boc), 2.19 and $2.22\left(2 \mathrm{~s}, 3 \mathrm{H}, \gamma \mathrm{CH}_{3}\right), 3.15(\mathrm{~s}, 3 \mathrm{H}$, $\left.\mathrm{OCH}_{3}\right), 3.15-3.33\left(\mathrm{~m}, 2 \mathrm{H}, \beta_{\mathrm{CH}}\right), 4.59-4.64(\mathrm{~m}, 1 \mathrm{H}, \alpha \mathrm{CH}), 5.13$ (br. s, $1 \mathrm{H}, \mathrm{NH}), 7.30-7.40(\mathrm{~m}, 5 \mathrm{H}, \mathrm{ArH}), 7.72-7.81(\mathrm{~m}, 2 \mathrm{H}$, $\mathrm{ArH}), \quad 7.99-8.20(\mathrm{~m}, 8 \mathrm{H}, \mathrm{ArH}) \mathrm{ppm} .{ }^{13} \mathrm{C} \mathrm{NMR}(100.6 \mathrm{MHz}$,

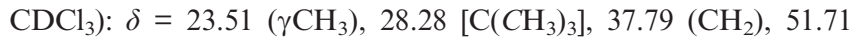
$\left(\mathrm{OCH}_{3}\right), 56.03(\mathrm{CH}), 80.63\left[\mathrm{OC}\left(\mathrm{CH}_{3}\right)_{3}\right], 124.39(\mathrm{C}), 124.48(\mathrm{CH})$, $124.56(\mathrm{CH}), 124.59(\mathrm{CH}), 124.67(\mathrm{C}), 124.81(\mathrm{C}), 125.04(\mathrm{CH})$, 125.08 (CH), $125.94(\mathrm{CH}), 127.09(\mathrm{CH}), 127.29(\mathrm{CH}), 127.37(\mathrm{CH})$, $127.49(\mathrm{C}), 127.54(\mathrm{C}), 127.82(\mathrm{CH}), 128.79(\mathrm{CH}), 129.43(\mathrm{CH})$, 130.52 (C), 131.02 (C), 131.32 (C), 136.57 (C), 143.73 (C), 155.77 $(\mathrm{C}=\mathrm{O}), 164.38(\mathrm{C}=\mathrm{O}), 170.05(\mathrm{C}=\mathrm{O}) \mathrm{ppm}$. HRMS (ESI): calcd. for $\mathrm{C}_{35} \mathrm{H}_{35} \mathrm{~N}_{2} \mathrm{O}_{5}[\mathrm{M}+\mathrm{H}]^{+}$563.2546; found 563.2541.

Synthesis of Compound $(Z)-13$ : Compound $(Z)-\mathbf{1 3}$ was prepared from compound $(Z)-\mathbf{1 1}(0.300 \mathrm{mmol}, 124 \mathrm{mg})$ according to the general procedure described above, heating for $1.5 \mathrm{~h}$. Column chromatography using diethyl ether/petroleum ether (1:1) gave (Z)$13(130 \mathrm{mg}, 81 \%)$ as a white solid; m.p. $222.5-223.0^{\circ} \mathrm{C}$ (from diethyl ether $/ n$-hexane). ${ }^{1} \mathrm{H}$ NMR $\left(300 \mathrm{MHz}, \mathrm{CDCl}_{3}\right): \delta=0.93$ (s, 9 $\mathrm{H}, \mathrm{CH}_{3}$ Boc), 3.44-3.51 (m, $2 \mathrm{H}, \mathrm{CH}_{2} \mathrm{Gly}$ ), 3.69 (s, $3 \mathrm{H}, \mathrm{OCH}_{3}$ ), 4.68 (br. s, $1 \mathrm{H}, \mathrm{NH}), 7.23-7.29$ (m, $6 \mathrm{H}, \mathrm{ArH}+\mathrm{NH}), 7.77$ (d, $J$ $=7.8 \mathrm{~Hz}, 1 \mathrm{H}, \mathrm{ArH}), 8.04-8.25(\mathrm{~m}, 8 \mathrm{H}, \mathrm{ArH}) \mathrm{ppm} .{ }^{13} \mathrm{C} \mathrm{NMR}$ $\left(100.6 \mathrm{MHz}, \mathrm{CDCl}_{3}\right): \delta=27.63\left[\mathrm{C}\left(\mathrm{CH}_{3}\right)_{3}\right], 43.96\left(\mathrm{CH}_{2}\right), 52.35$ $\left(\mathrm{OCH}_{3}\right), 79.90\left[\mathrm{OC}\left(\mathrm{CH}_{3}\right)_{3}\right], 124.13(\mathrm{CH}), 124.65(\mathrm{C}), 124.98(\mathrm{C})$, $125.11(\mathrm{CH}), 125.65(\mathrm{CH}), 125.75(\mathrm{CH}), 126.31(\mathrm{CH}), 126.68(\mathrm{C})$, $127.17(\mathrm{CH}), 127.92(\mathrm{CH}), 128.14(\mathrm{CH}), 128.25(\mathrm{CH}), 128.27(\mathrm{CH})$, $128.41(\mathrm{C}), 128.64(\mathrm{CH}), 128.84(\mathrm{CH}), 130.76(\mathrm{C}), 131.21(\mathrm{C})$, 131.57 (C), 131.95 (C), 133.53 (C), 139.44 (C), 155.28 (C=O), $165.99(\mathrm{C}=\mathrm{O}), 167.90(\mathrm{C}=\mathrm{O})$ ppm. $\mathrm{C}_{33} \mathrm{H}_{30} \mathrm{~N}_{2} \mathrm{O}_{5}(534.60)$ : calcd. $\mathrm{C}$ 74.14, H 5.66, N 5.24; found C 73.90, H 5.47, N 5.24.

\section{Acknowledgments}

We thank the Portuguese Foundation for Science and Technology (FCT) and the European Communautaire Fund (FEDER) for fin- 
ancial support through the Centro de Química (POCTI-SFA-3-686) and the Centro de Física of University of Minho (POCI/QUI/ 59407/2004) and for a post-doctoral grant awarded to A. S. A. (SFRH/BPD/24548/2005).

[1] a) P. M. T. Ferreira, H. L. S. Maia, L. S. Monteiro, J. Sacramento, J. Sebatião, J. Chem. Soc. Perkin Trans. 1 2000, $3317-$ 3324; b) P. M. T. Ferreira, H. L. S. Maia, L. S. Monteiro, J. Sacramento, J. Chem. Soc. Perkin Trans. 1 2001, 3167-3174.

[2] P. M. T. Ferreira, L. S. Monteiro, Eur. J. Org. Chem. 2006, 3226-3234.

[3] a) P. M. T. Ferreira, H. L. S. Maia, L. S. Monteiro, Tetrahedron Lett. 2002, 43, 4491-4493; b) P. M. T. Ferreira, H. L. S. Maia, L. S. Monteiro, Eur. J. Org. Chem. 2003, 2635-2644.

[4] P. M. T. Ferreira, L. S. Monteiro, G. Pereira, L. Ribeiro, J. Sacramento, L. Silva, Eur. J. Org. Chem. 2007, 5934-5949.

[5] a) N. O. Silva, A. S. Abreu, P. M. T. Ferreira, M. J. R. P. Queiroz, Tetrahedron Lett. 2003, 44, 3377-3379; b) A. S. Abreu, P. M. T. Ferreira, L. S. Monteiro, M. J. R. P. Queiroz, I. C. F. R. Ferreira, R. C. Calhelha, L. M. Estevinho, Tetrahedron 2004, 60, 11821-11828; c) A. S. Abreu, E. M. S. Castanheira, P. M. T. Ferreira, M. J. R. P. Queiroz, Tetrahedron 2007, 63, 2215-2222; M. J. Queiroz, A. S. Abreu, R. C. Calhelha, M. S. D. Carvalho, P. M. T. Ferreira, Tetrahedron 2008, 64, 5139-5146.

[6] a) S. Egusa, M. Sisido, Y. Imanishi, Macromolecules 1985, 18, 882-889; b) A. Szymańska, W. Wiczk, L. Lankiewicz, Amino Acids 2001, 21, 265-270; c) I. Alves, S. Cowell, Y. S. Lee, X. Tang, P. Davis, F. Porreca, V. J. Hruby, Biochem. Biophys. Res. Commun. 2004, 318, 335-340.
[7] P. M. T. Ferreira, H. L. S. Maia, L. S. Monteiro, J. Sacramento, Tetrahedron Lett. 2000, 41, 7437-7441.

[8] M. Hissler, A. Harriman, A. Khatyar, R. Ziessel, Chem. Eur. J. 1999, 5, 3366-3381.

[9] B. Valeur, Molecular Fluorescence - Principles and Applications, Wiley-VCH, Weinheim, 2002.

[10] a) K. Kalyanasundaran, J. K. Thomas, J. Am. Chem. Soc. 1977, 99, 2039-2044; b) D. C. Dong, M. A. Winnik, Can. J. Chem. 1984, 62, 2560-2565.

[11] M. Hissler, A. Harriman, A. Khatyr, R. Ziessel, Chem. Eur. J. 1999, 5, 3366-3381.

[12] A. Wiessner, G. Hüttmann, W. Kühnle, H. Staerk, J. Phys. Chem. 1995, 99, 14923-14930.

[13] S. Techert, S. Schmatz, A. Wiessner, H. Staerk, J. Phys. Chem. A 2000, 104, 5700-5710.

[14] W. Weigel, W. Rettig, M. Dekhtyar, C. Modrakowski, M. Beinhoff, A. D. Schlüter, J. Phys. Chem. A 2003, 107, 5941-5947.

[15] J. R. Lakowicz, Principles of Fluorescence Spectroscopy, Plenum Press, New York, 1983.

[16] J. N. Demas, G. A. Crosby, J. Phys. Chem. 1971, 75, 991-1024.

[17] S. Fery-Forgues, D. Lavabre, J. Chem. Educ. 1999, 76, 12601264.

[18] a) W. R. Dawson, M. W. Windsor, J. Phys. Chem. 1968, 72, 3251-3260; b) W. H. Melhuish, J. Phys. Chem. 1961, 65, 229235.

[19] P. M. T. Ferreira, H. L. S. Maia, L. S. Monteiro, J. Sacramento, J. Chem. Soc. Perkin Trans. 1 1999, 3697-3703.

Received: June 30, 2008 Published Online: October 22, 2008 